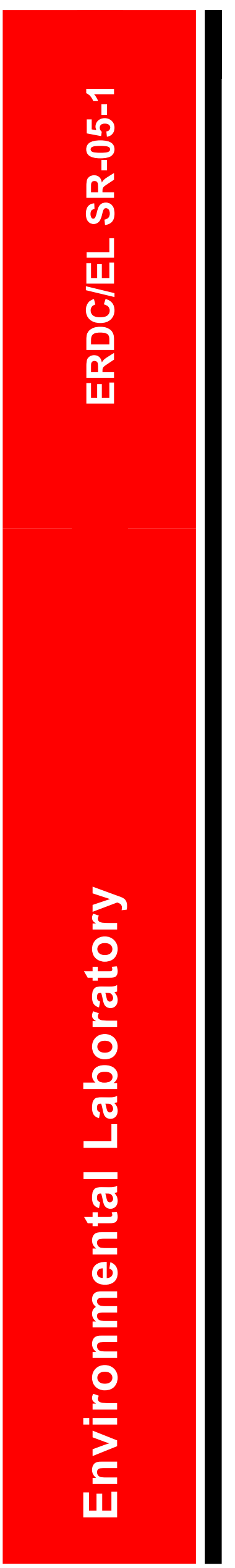

Aquatic Plant Control Research Program

\title{
A Survey of the Invasive Aquatic and Riparian Plants of the Lower Rio Grande, 2004
}

Chetta S. Owens, Michael J. Grodowitz, and Fred Nibling 


\section{A Survey of the Invasive Aquatic and Riparian Plants of the Lower Rio Grande, 2004}

Chetta S. Owens

Analytical Services Inc.

Lewisville Aquatic Ecosystem Research Facility

U.S. Army Engineer Research and Development Center

201 E. Jones St.

Lewisville, TX 75057

Michael J. Grodowitz

Environmental Laboratory

U.S. Army Engineer Research and Development Center

3909 Halls Ferry Road

Vicksburg, MS 39180-6199

Fred Nibling

U.S. Department of Interior, Bureau of Reclamation

P.O. Box 25007

Denver, CO 80225

Final report

Approved for public release; distribution is unlimited 


\begin{abstract}
Hydrilla has exhibited extensive range expansion along the Rio Grande since it was first discovered in early 1990 and is now found in areas far removed from the original infestation in Brownsville, TX. Hydrilla, a nonindigenous aquatic plant species, has been implicated in restricted water delivery, inaccurate water accounting, and an overall breakdown of system maintenance. The presence of hydrilla also has had a decided impact on native flora by the formation of extensive monocultures in many areas.

In 2004, surveys were conducted starting below Amistad Reservoir to immediately below Falcon Reservoir to assess the distribution and expansion of hydrilla infestations and document the presence of other invasive aquatic and riparian plant species. A total of seven nonindigenous plant species, hydrilla (Hydrilla verticillata), Eurasian watermilfoil (Myriophyllum spicatum), parrotfeather (M. aquaticum), elephant-ear (Colcasia esculenta), giant cane (Arundo donax), salt cedar (Tamarisk spp.), and castorbean (Ricinus communis) were observed. Hydrilla infestations that were originally discovered during $2003 \mathrm{had}$ increased in size through localized stolon expansion. Also, new hydrilla sites were discovered in 2004, including several directly below Amistad Reservoir. No hydrilla was discovered immediately south of Laredo; however, hydrilla infestations had dramatically increased below Falcon Reservoir. Giant cane continues to spread down river, even displacing well-established common cane (Phragmites australis) below Falcon Reservoir. While no new Eurasian watermilfoil sites were discovered in 2004, existing infestations near Del Rio remain stable, extending bank-to-bank and considerable distances down the river. Eurasian watermilfoil fragments, which could lead to the formation of new infestations downstream, were observed in the river. Numerous new sites of parrotfeather, elephant-ear, and salt cedar were found during the 2004 survey, and all sites identified in 2003 had increased in localized spread. One endangered wetland plant species, Correll's false dragonhead (Physostegia correllii), was tentatively identified.
\end{abstract}

DISCLAIMER: The contents of this report are not to be used for advertising, publication, or promotional purposes. Citation of trade names does not constitute an official endorsement or approval of the use of such commercial products. All product names and trademarks cited are the property of their respective owners. The findings of this report are not to be construed as an official Department of the Army position unless so designated by other authorized documents. 


\section{Contents}

Conversion Factors, Non-SI to SI Units of Measurement.................................. vi

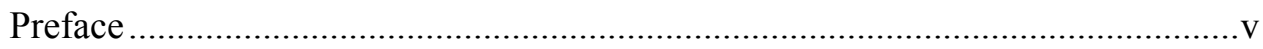

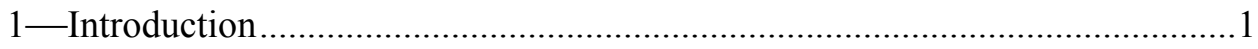

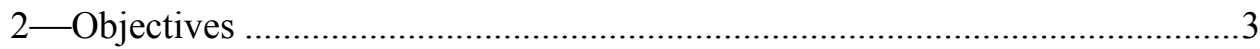

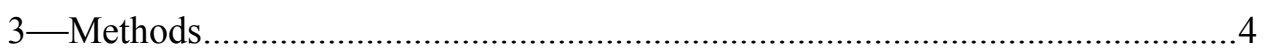

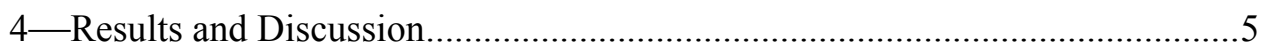

Hydrilla and Other Introduced Weedy Species ...........................................5

Native Plant Species on the Rio Grande ................................................... 12

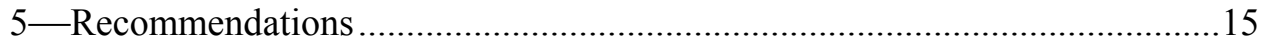

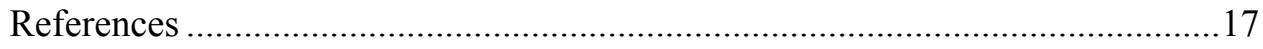

SF 298

\section{List of Figures}

Figure 1. Areas of the Rio Grande sampled during 2003 and 2004 ...........2

Figure 2. Sites on the Rio Grande where hydrilla was observed during 2003 surveys .............................................................

Figure 3. Areas of the Rio Grande surveyed where hydrilla

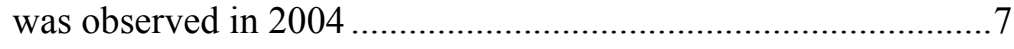

Figure 4. Hydrilla fragments floating in the Rio Grande............................8

Figure 5. Extensive hydrilla mat at Roma, TX ...................................... 9

Figure 6. Giant cane infestation on the river ........................................... 9

Figure 7. Bank-to-bank mat of Eurasian watermilfoil immediately upriver of Maverick Irrigation District intake ...........................10

Figure 8. Parrotfeather infestation at Lonesome Dove ............................11 
Figure 9. Elephant-ear occupies the niche between giant cane and the river ........................................................................

Figure 10. Salt cedar encroaching into riparian regions below Amistad Reservoir... 12

Figure 11. Castorbean invasion along the Rio Grande .13

Figure 12. Tentative discovery of Correll's false dragonhead on the Rio Grande

Figure 13. Potential nutrient input from Mexico into the Rio Grande and large intermixed plant bed below outfall 


\section{Conversion Factors, Non-SI to SI Units of Measurement}

Non-SI units of measurement used in this report can be converted to SI units as follows:

\begin{tabular}{|l|l|l||}
\hline Multiply & By & To Obtain \\
\hline \hline feet & 0.3048 & meters \\
\hline miles (U.S. statute) & 1.609347 & kilometers \\
\hline
\end{tabular}




\section{Preface}

The work reported herein was conducted as part of the Aquatic Plant Control Research Program (APCRP). The APCRP is sponsored by Headquarters, U.S. Army Corps of Engineers (HQUSACE), and is assigned to the U.S. Army Engineer Research and Development Center (ERDC) under the purview of the Environmental Laboratory (EL). Funding was provided under Department of the Army Appropriation Number 96X3122, Construction General. Mr. Robert C. Gunkel, Jr., EL, ERDC, was Program Manager, APCRP. Program Monitor during this investigation was Mr. Timothy R. Toplisek, HQUSACE.

The authors wish to thank Dr. Judy F. Shearer and Joe R. Snow, EL, for reviewing the paper, Lavon L. Jeffers, EL, for creating the maps, and the Texas Commission of Environmental Quality, Texas Parks and Wildlife, and U.S. Border Patrol for providing assistance during this research project.

This work was performed under the general supervision of Dr. Elizabeth Fleming, Acting Director, EL.

COL James R. Rowan, EN, was Commander and Executive Director of ERDC. Dr. James R. Houston was Director. 


\section{Introduction}

The Rio Grande is the nation's second longest river, almost 2,000 miles ${ }^{1}$ of which forms an international boundary between the United States and Mexico. Since much of the Rio Grande flows through arid lands, water is a scarce and valuable resource, and introduced invasive plant species can potentially affect water flows, quantity, and quality. Invasive species such as hydrilla (Hydrilla verticillata) and water hyacinth (Eichhornia crassipes) in the lower Rio Grande have been implicated in the inability of the river to reach the Gulf of Mexico. Problems with hydrilla in the lower Rio Grande raised concerns about hydrilla in the middle section of the river, providing impetus to survey for hydrilla infestations in the middle Rio Grande.

Hydrilla was first observed on sections of the lower Rio Grande in the late 1990s. The plant exhibits aggressive growth strategies, rapidly expanding to the surface and forming a dense canopy that restricts water delivery, allows for inaccurate water accounting, and contributes to an overall breakdown of system maintenance (Chilton 2002, Nibling and Grodowitz 2001). Once hydrilla invades an aquatic ecosystem, several factors contribute to its spread, including localized spread through development of stolons and subterranean tubers, and dispersal via axillary turion releases and fragmentation (Madsen and Owens 1998). Hydrilla has exhibited extensive range expansions along the Rio Grande and is now found in areas far removed from the original infestations. Since hydrilla has several highly efficient mechanisms for dispersal, it is important to document its presence along the Rio Grande and develop more efficient management programs to inhibit new infestations locally and downstream.

In August 2004, the Rio Grande was surveyed for the third year for the presence of hydrilla and other invasive aquatic weed species. Although greater sections of the river were surveyed in 2004 because of airboat availability, difficulties in accessing the river did not allow complete examination of the 300 river miles from Amistad to 25 miles south of Falcon Reservoir (Figure 1). New access sites are being determined. Results from past surveys can be found in Nibling and Grodowitz (2001) and Owens et al. (2005).

\footnotetext{
${ }^{1}$ A table of factors for converting non-SI units of measurement to SI units is presented on page $\mathrm{v}$.
} 


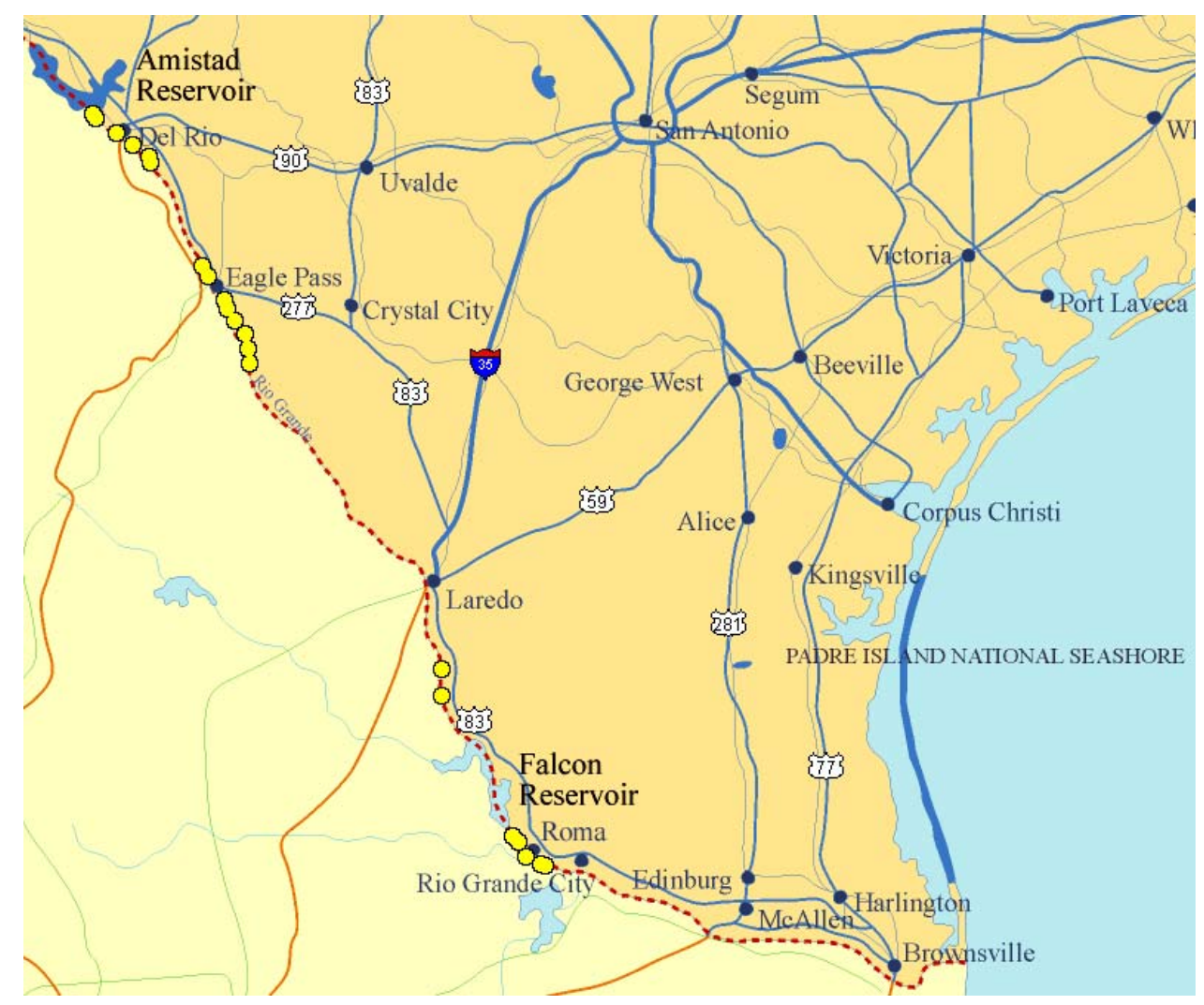

Figure 1. Areas of the Rio Grande sampled during 2003 and 2004 


\section{Objectives}

The primary objectives of this study included:

a. Locating new hydrilla infestations that were not observed during the 2003 survey, and qualitatively determining the extent of localized spread from colonies that were found during the 2003 survey.

b. Determining the presence or absence of other invasive weed species threatening the Rio Grande.

The secondary objectives included:

a. Evaluating introduced leaf-mining fly (Hydrellia spp.) population numbers and leaf damage on release sites, and identifying potential new release areas for this biocontrol agent.

b. Locating and identifying native aquatic, wetland, and riparian plant species. 


\section{Methods}

Between 16 and 20 August 2004, seven sites on the Rio Grande were surveyed via airboat from below Amistad Reservoir to 25 river miles below Falcon Reservoir (Figure 1). The 2004 survey was conducted to reassess hydrilla sites that were discovered during the 2003 survey (Owens et al. 2005), to determine spread, and to identify new infestations of hydrilla and other invasive aquatic and riparian species. All sites, except for Indio (boat trouble), were reassessed during the 2004 survey and a new portion of the river (approximately 15 river miles below Laredo) was added. Also, the lower region of the Maverick Irrigation District canal around Laredo was surveyed. At all hydrilla sites, samples were collected to determine presence of the larval stages of the introduced insect biological control agents Hydrellia pakistanae and H. balciunasi. Samples of Eurasian watermilfoil also were collected to check for native insect herbivores and fungal pathogens. 


\section{Results and Discussion}

Five new species were discovered during 2004, including three native submersed aquatic plants, one native soon-to-be listed endangered emergent plant, and one nonnative emergent plant (Table 1). Total numbers of species observed during the 2003 - 2004 surveys now include seven nonindigenous plants, ten submersed native plants, and ten emergent native plants. The same two algal species observed in 2003, muskgrass (Chara spp.) and black moss (Lyngbya wollei), were also observed in 2004.

\section{Hydrilla and Other Introduced Weedy Species}

Several small infestations of hydrilla were observed during the 2003 survey in the area of the river accessed from Del Rio, TX (Figure 2). These hydrilla sites were reassessed in 2004 and generally found to have expanded in size. Also, numerous new sites were located, especially immediately below Amistad Dam (Figure 3). Extensive hydrilla infestations occur in Amistad Reservoir, thus providing the propagule source for fragment and turion dispersal into the river (Figure 4).

In addition to the Del Rio area, all hydrilla sites discovered near Eagle Pass during the 2003 survey were reassessed in 2004. Most of the sites discovered in 2003 had expanded and several new sites were identified. They were typically along the edges of the river or in coves where hydrilla fragments apparently had settled, rooted, and established.

A section of the river starting in Zapata, TX, south of Laredo was monitored in 2004. No submersed vegetation including hydrilla was discovered in this portion of the river. Either appropriate propagules have not yet reached this section or the river water is too turbid for submersed plant growth.

The Maverick Irrigation District canal starts above Eagle Pass, TX, and continues for about 100 miles to immediately south of Laredo, TX. Fragments of hydrilla were found in the Maverick Irrigation District trash racks during 2003 and 2004. Mats of "topped out" hydrilla were found in the end of the canal in 2004. The entire canal has not been surveyed, but with an average water depth of $4 \mathrm{ft}$, hydrilla has the potential to completely cover the entire $100+$ miles of the Maverick Irrigation District canal. 


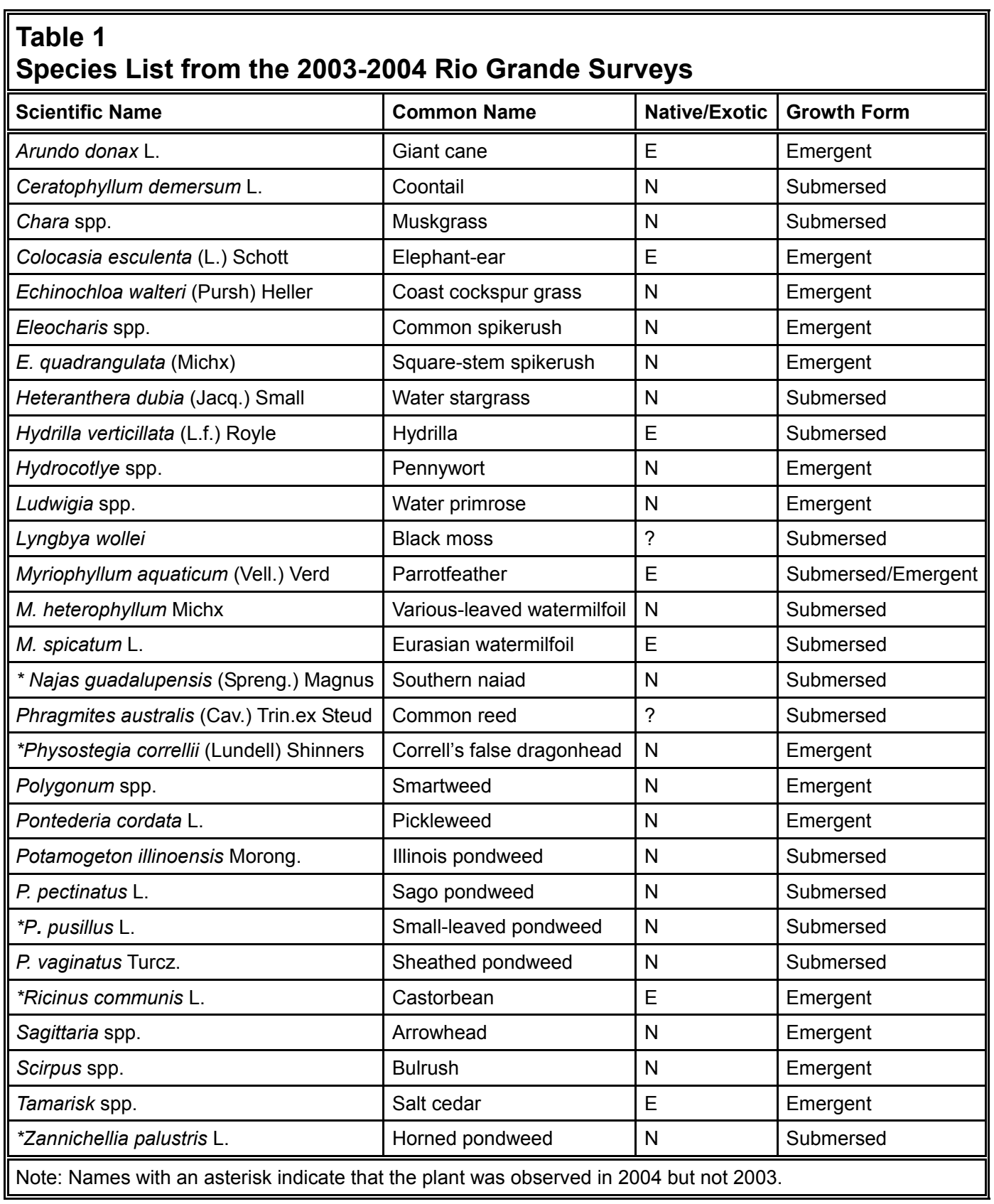




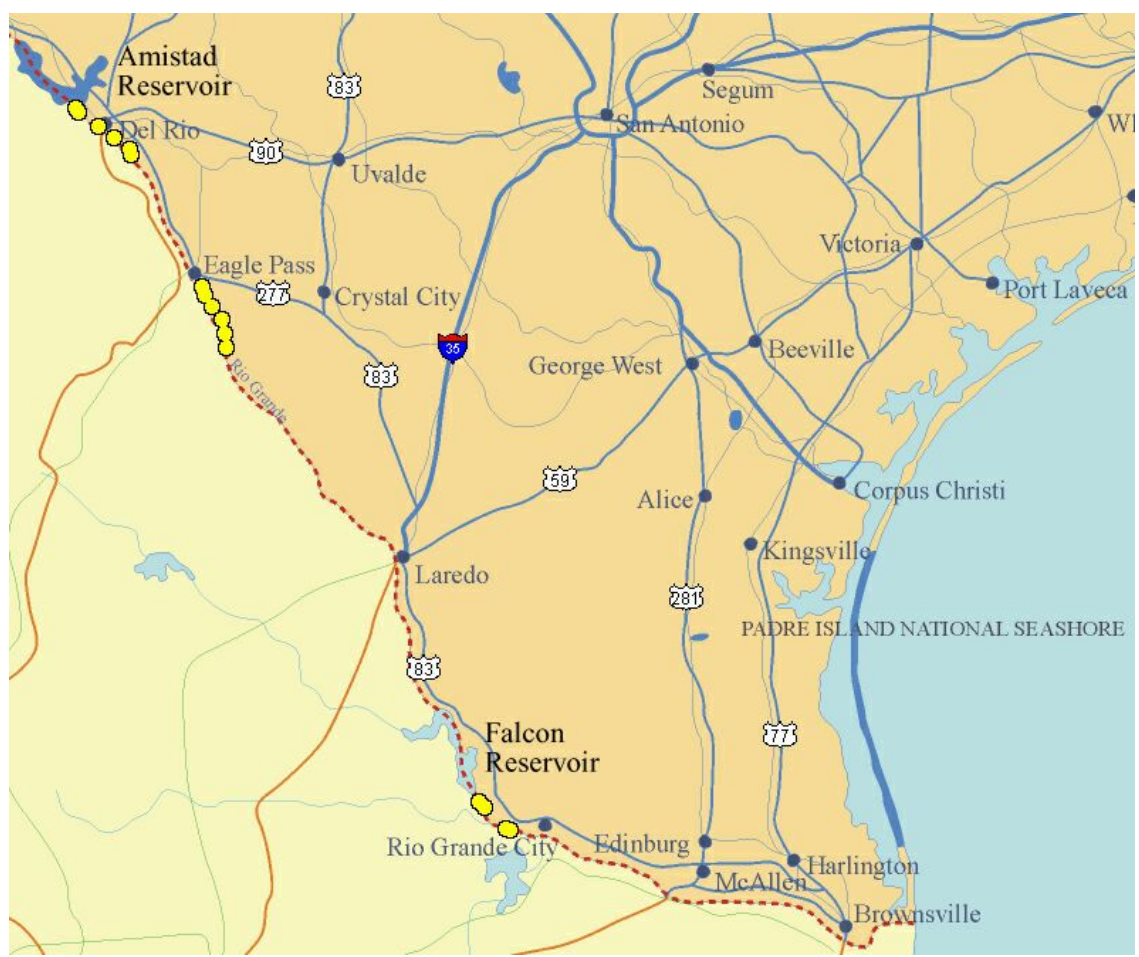

Figure 2. Sites on the Rio Grande where hydrilla was observed during 2003 surveys

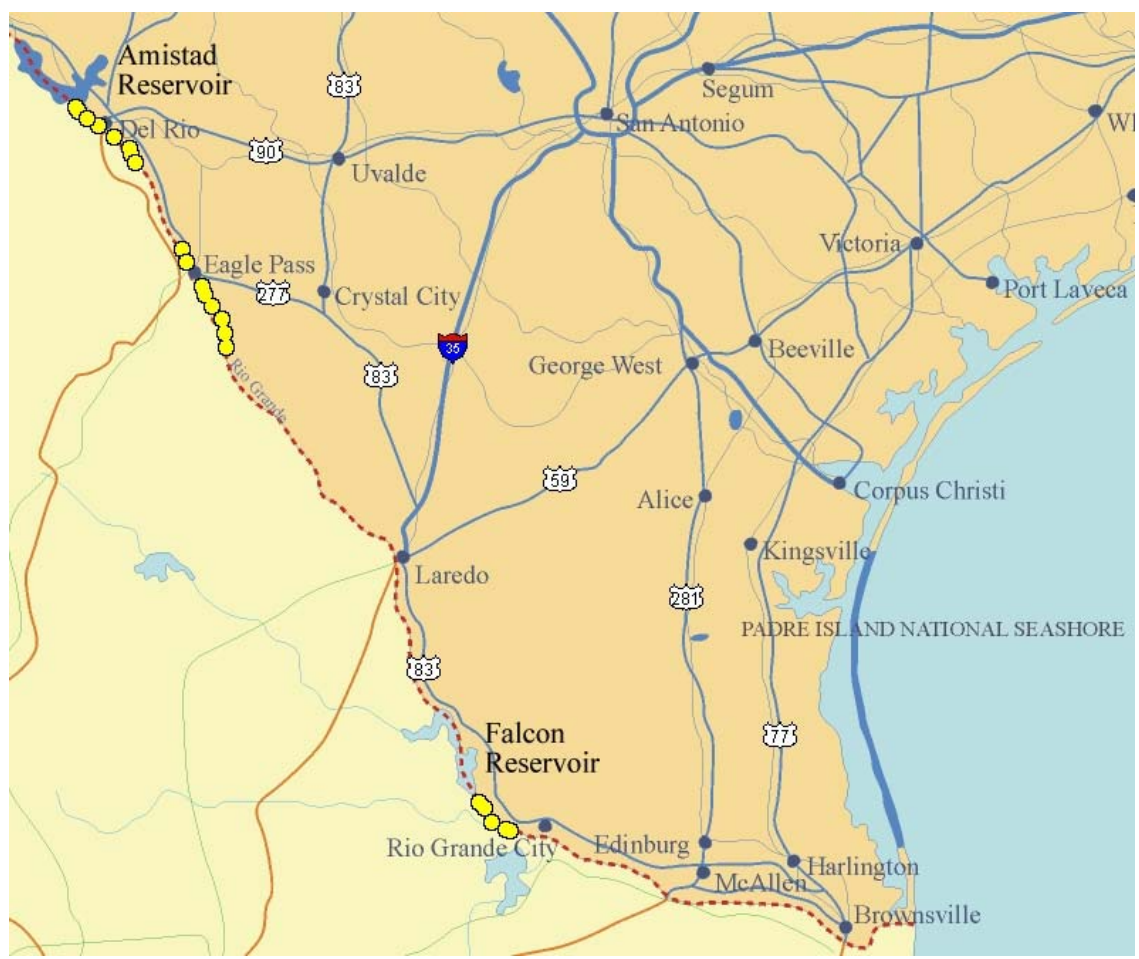

Figure 3. Areas of the Rio Grande surveyed where hydrilla was observed in 2004 


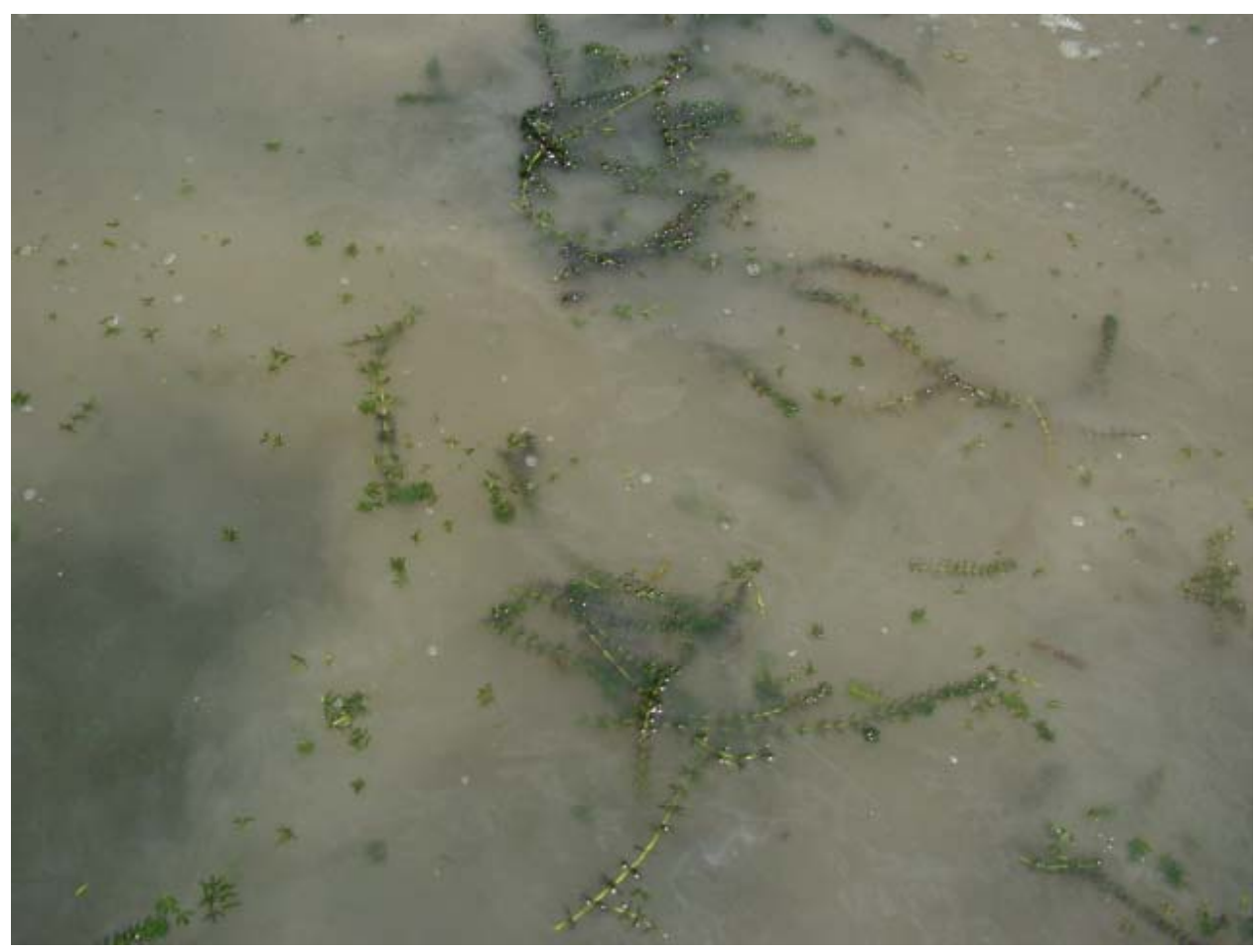

Figure 4. Hydrilla fragments floating in the Rio Grande

Because "topped out" hydrilla infestations have been observed in Falcon Reservoir and in the river below the reservoir, the stretch of the river from Roma, TX, to the reservoir was extensively surveyed. Hydrilla was observed at every river mile point for 25 miles below Falcon Reservoir, and at many sites the hydrilla reached bank to bank (Figure 5). In addition to observing hydrilla, the plants were sampled for the presence of the biocontrol agents Hydrellia pakistanae and $H$. balciunasi. Releases of these biocontrol agents have been made on several areas of the river including Roma, Lonesome Dove, and Falcon Reservoir. During the 2004 survey, low numbers of adult Hydrellia flies were hand-collected from several hydrilla sites below Falcon Reservoir and larvae were found in the collected hydrilla biomass.

While the main objective of the 2004 survey was to locate and monitor hydrilla infestations in the river, other introduced and potentially damaging plant species were monitored, including giant cane, elephant-ear, Eurasian watermilfoil, parrotfeather, salt cedar, and castorbean. According to data collected during the 2001 (Nibling and Grodowitz 2001) and 2003 (Owens et al. 2005) surveys, extensive stands of giant cane were found from Del Rio to Zapata, TX. Below Zapata, common cane is dominant, although each year more giant cane displaces native riparian and wetland vegetation along the river corridor (Figure 6). More information is available on giant cane from the 2003 report (Owens et al. 2005). 


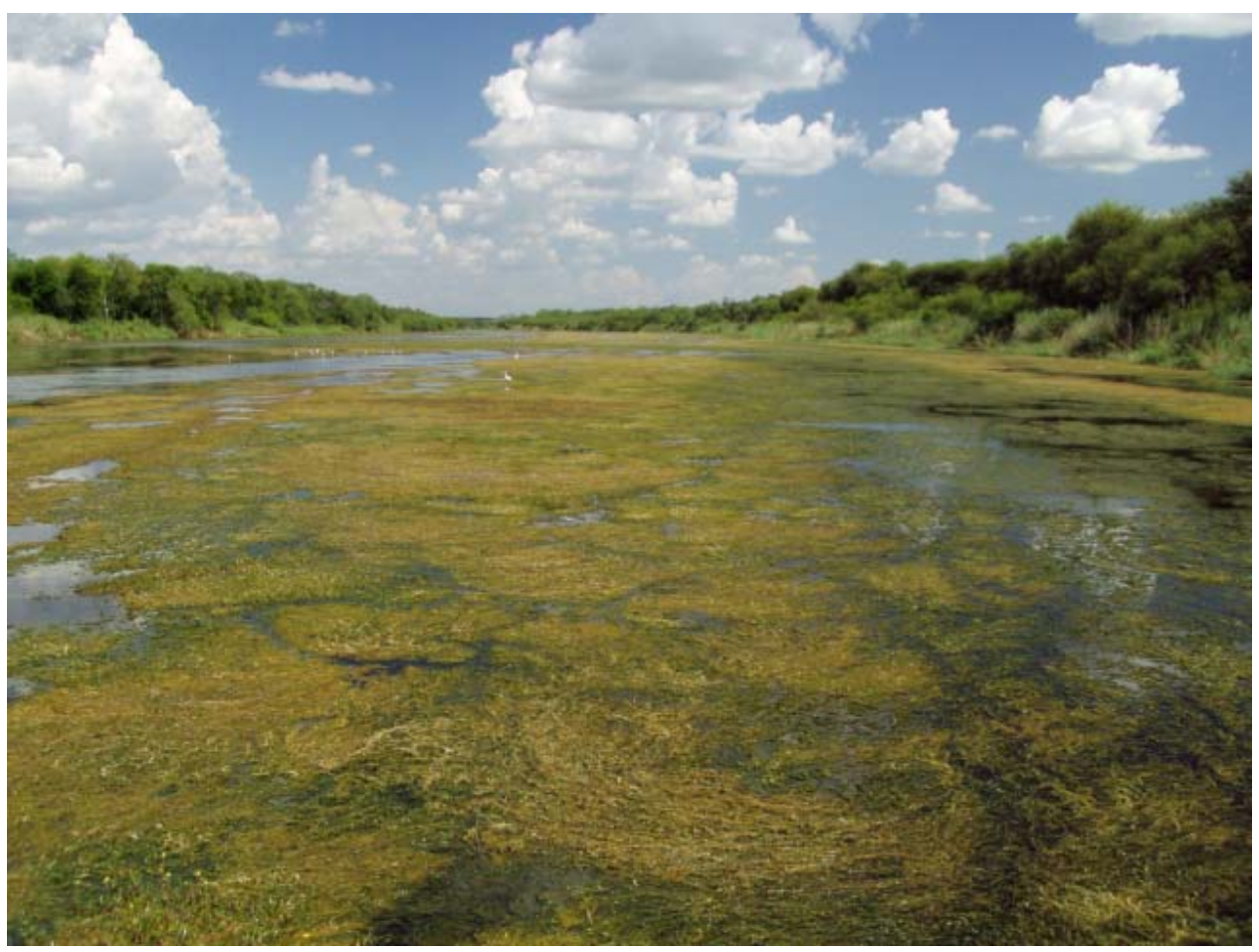

Figure 5. Extensive hydrilla mat at Roma, TX

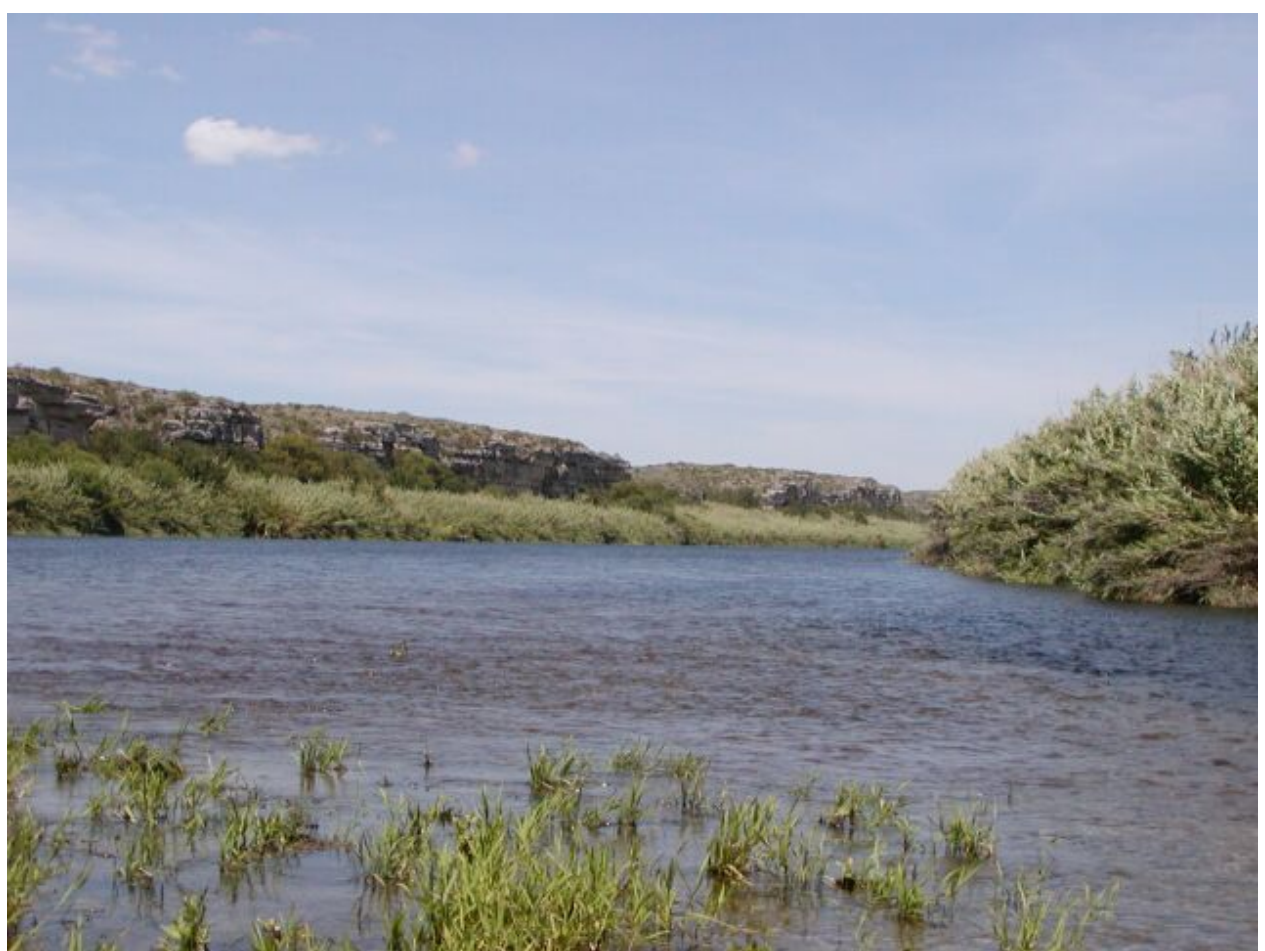

Figure 6. Giant cane infestation on the river

Eurasian watermilfoil appeared to occupy the same area in the river in 2004 as was observed in 2003 (Owens et al. 2005). No new sites were found although 
large mats were still visible (Figure 7). Although not observed in 2003, small hydrilla infestations were evident along the edge of Eurasian watermilfoil mats in 2004. Laboratory examination of collected Eurasian watermilfoil samples yielded no native insect herbivores but Mt (Mycoletodiscus terrestris), a fungal endophyte, was identified. ${ }^{1}$ Evidence from previous studies has shown that $\mathrm{Mt}$ can become pathogenic and have a detrimental effect on Eurasian watermilfoil (Shearer 2001).

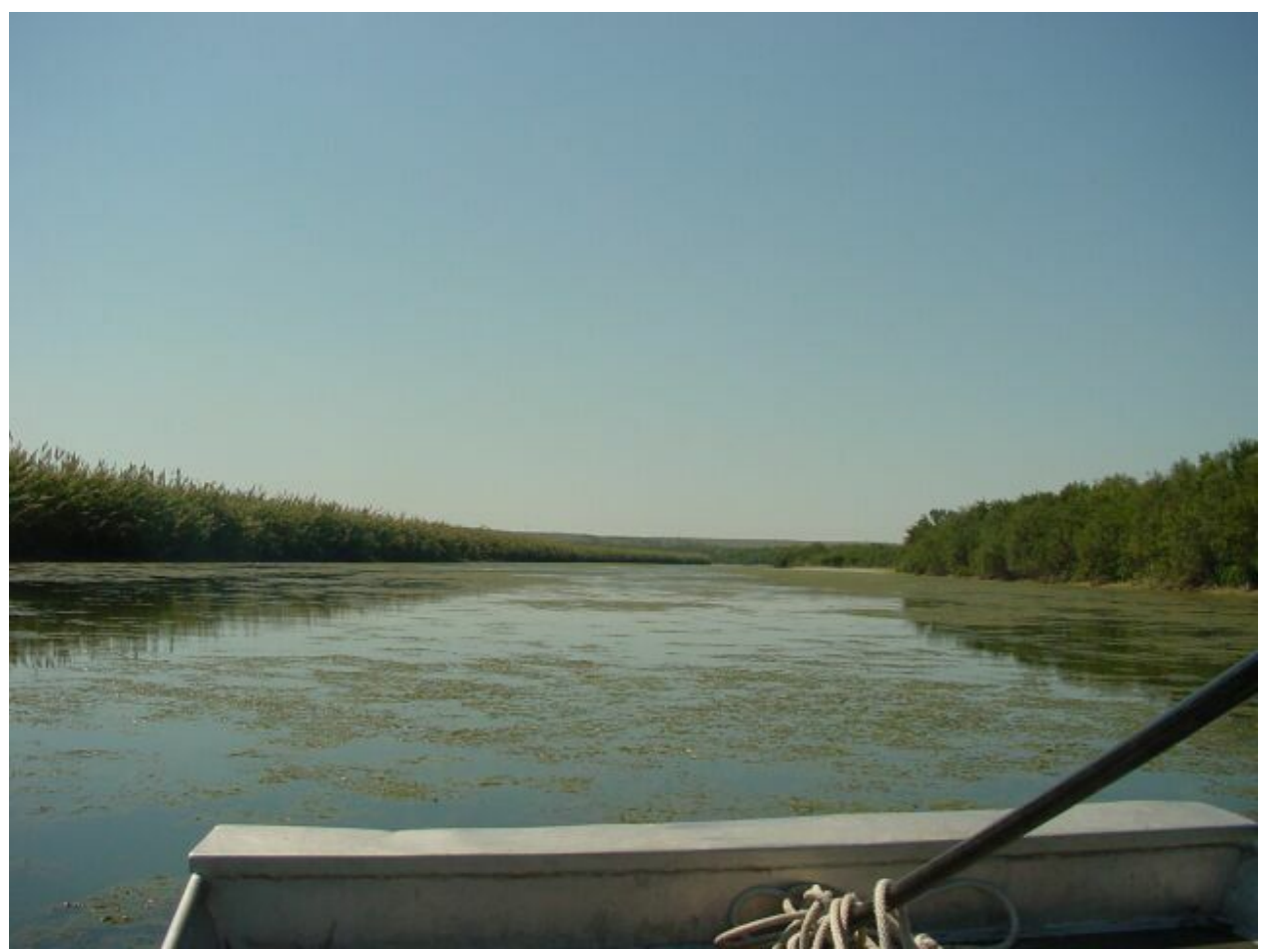

Figure 7. Bank-to-bank mat of Eurasian watermilfoil immediately upriver of Maverick Irrigation District intake

Parrotfeather (Figure 8) and elephant-ear (Figure 9) infestations first discovered during the 2003 survey have spread locally and newly infested areas were observed in 2004. Still at minimal infestation levels in the Rio Grande it should be noted that both of these nonindigenous species have severely affected other river systems in the southwest such as the Colorado River, AZ (Nibling, pers comm.), and the San Marcos River, TX (Owens et al. 2001).

Salt cedar is an extensive problem farther upriver on the Rio Grande and was also observed in the Del Rio and Eagle Pass survey areas in 2003 and 2004. Although the riparian niche is generally occupied by giant cane in this section of the river, it should be noted that more salt cedar was observed in 2004 than the previous year and that this invasive species possesses excellent dispersal mechanisms (Figure 10).

${ }^{1}$ J. Shearer, U.S. Army Engineer Research and Development Center, Vicksburg, MS. 


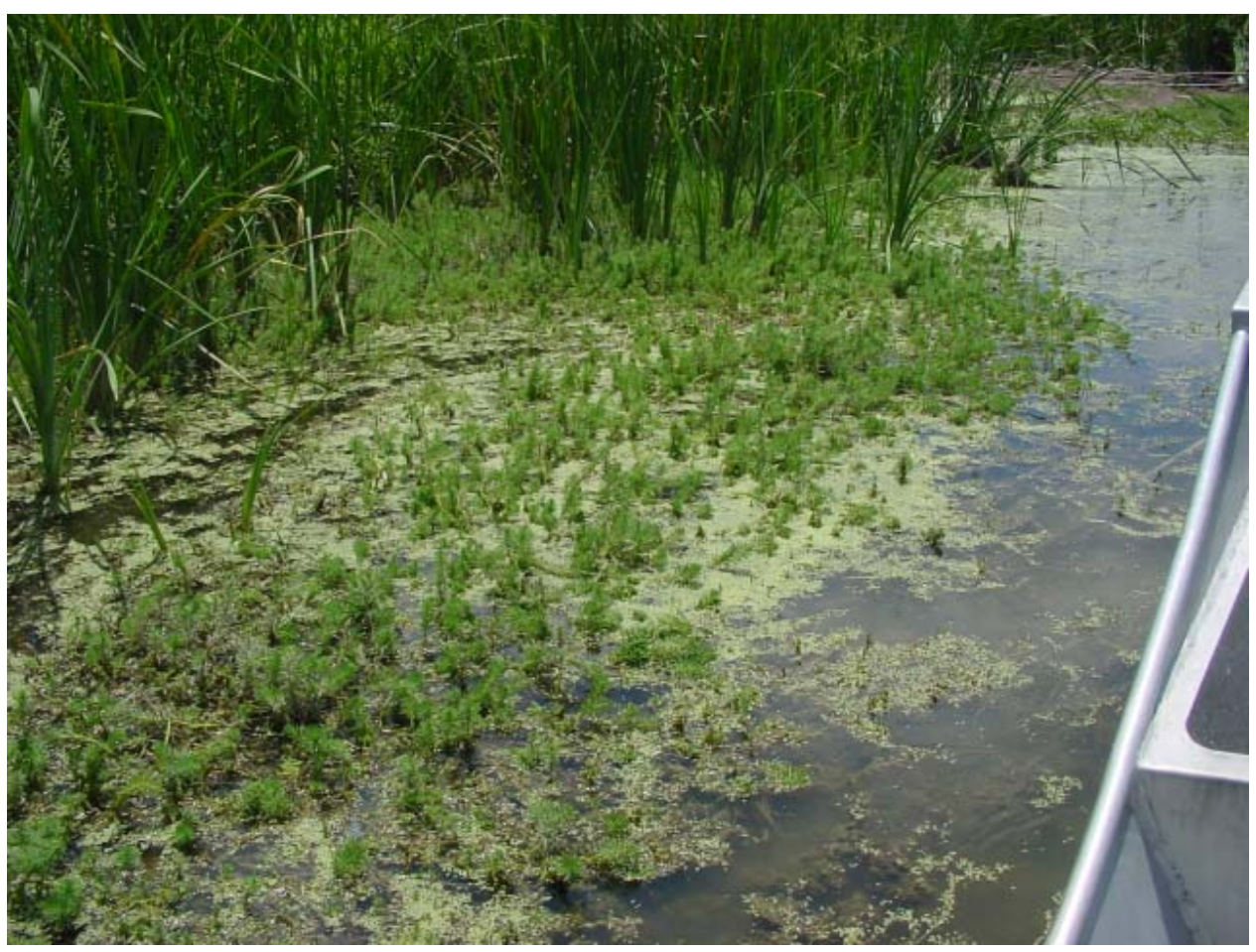

Figure 8. Parrotfeather infestation at Lonesome Dove

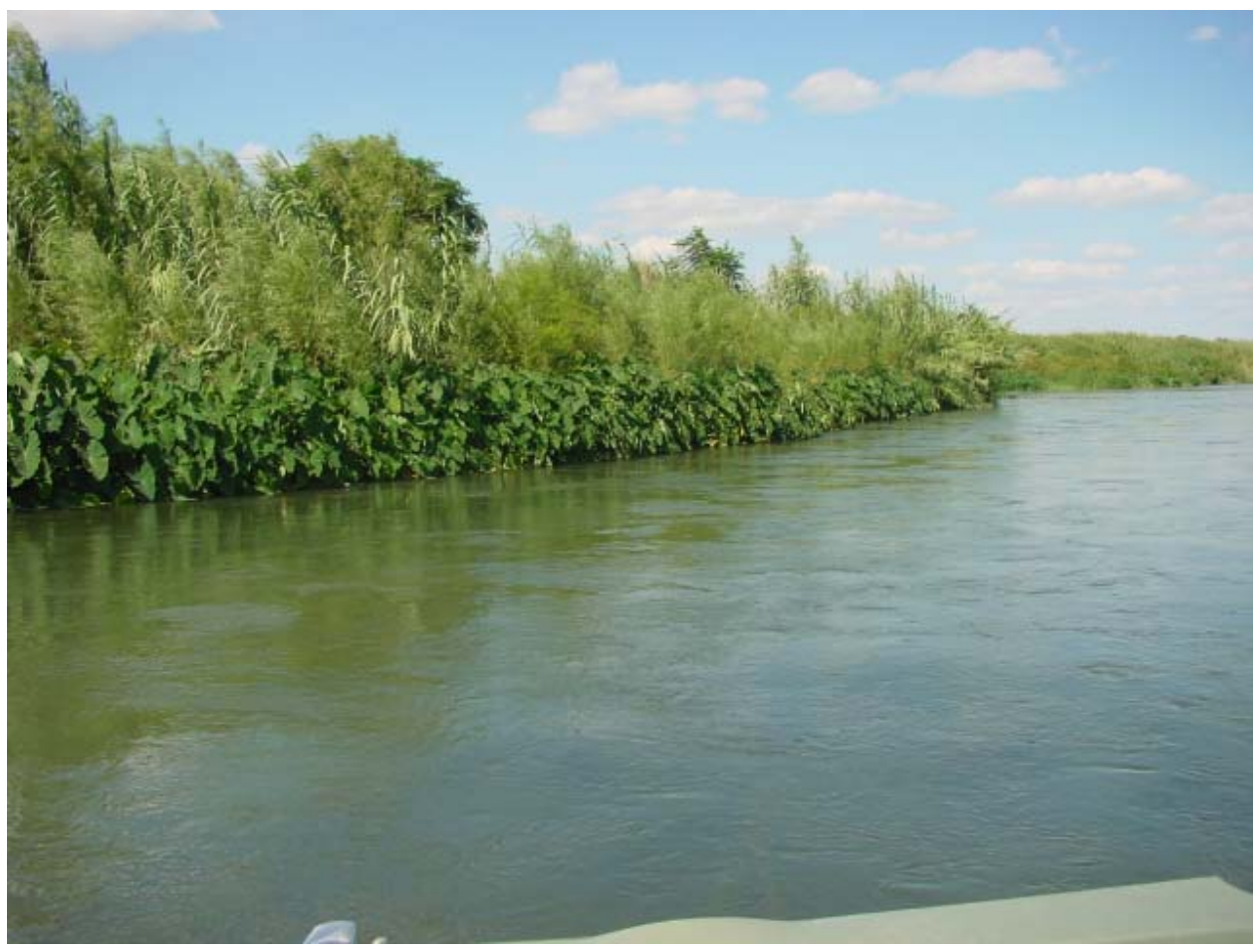

Figure 9. Elephant-ear occupies the niche between giant cane and the river 


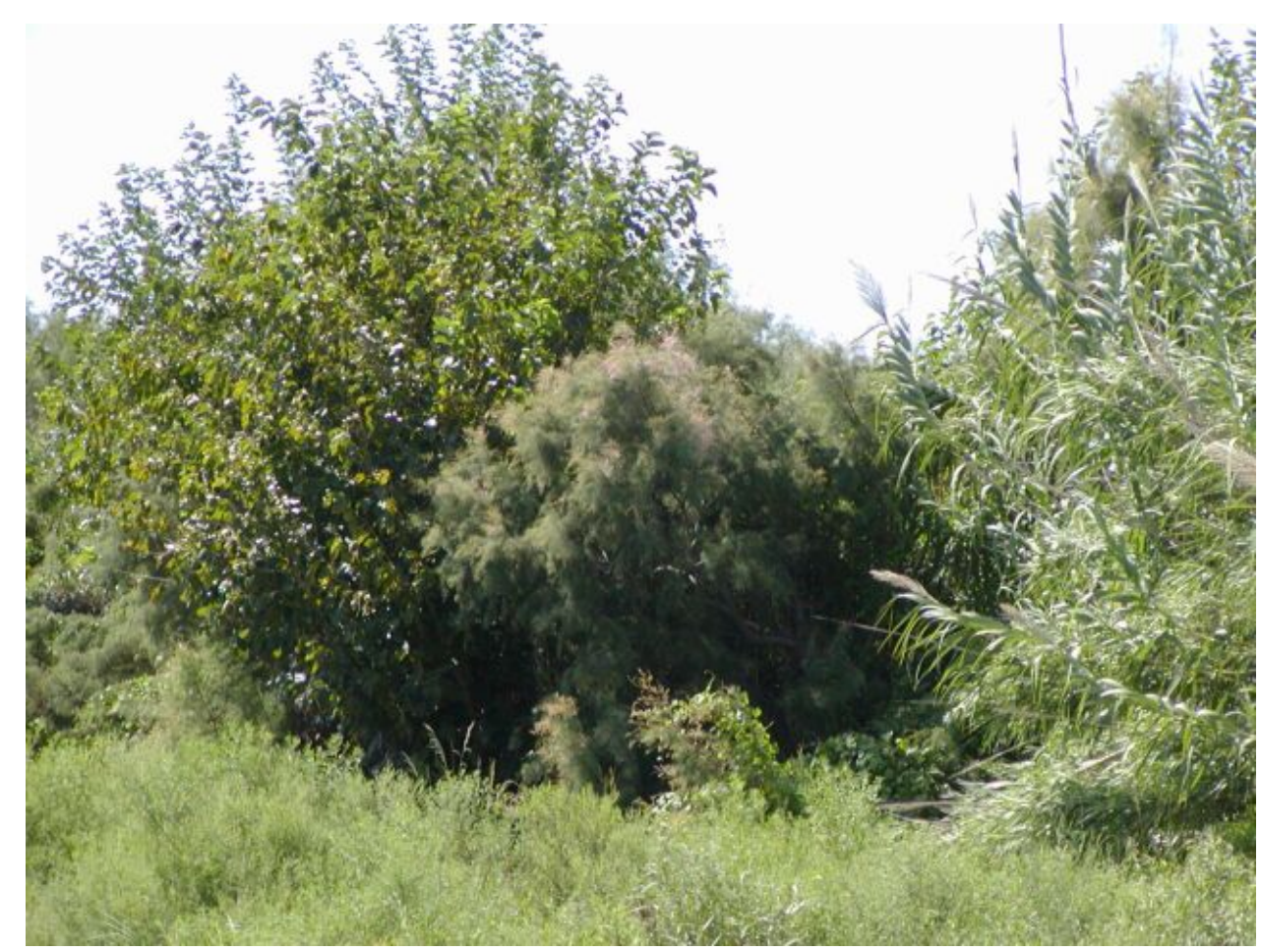

Figure 10. Salt cedar encroaching into riparian regions below Amistad Reservoir

Several castorbean plants were observed below Falcon Reservoir during the 2004 survey (Figure 11). Although the current distribution of this invasive plant is minimal on the river, this nonindigenous shrub/tree can be found in 24 states where it severely affects wetland areas as well as stream and riverbanks and bottomlands in warm climates ( $w w w$.plants.usda.gov). The seeds from the castorbean are poisonous to people, animals, and insects (www.ansci.cornell.edu/plants/).

\section{Native Plant Species on the Rio Grande}

While the same native aquatic and riparian plants were found during the 2004 survey in the Rio Grande as in 2003, four new plants were also identified. The new aquatic plants found in the Del Rio area of the river include southern naiad (Najas guadalupensis), small-leaf pondweed (Potamogeton pusillus), and horned pondweed (Zannichellia palustris) (Table 1). Also, Correll's false dragonhead (Physostegia correllii (Lundell) Shinners), an emergent wetland plant, was tentatively identified (Figure 12). Future visits by Texas Parks and Wildlife personnel will positively identify this wetland species. Considered endangered in Texas, this extant population currently represents a significant discovery. 


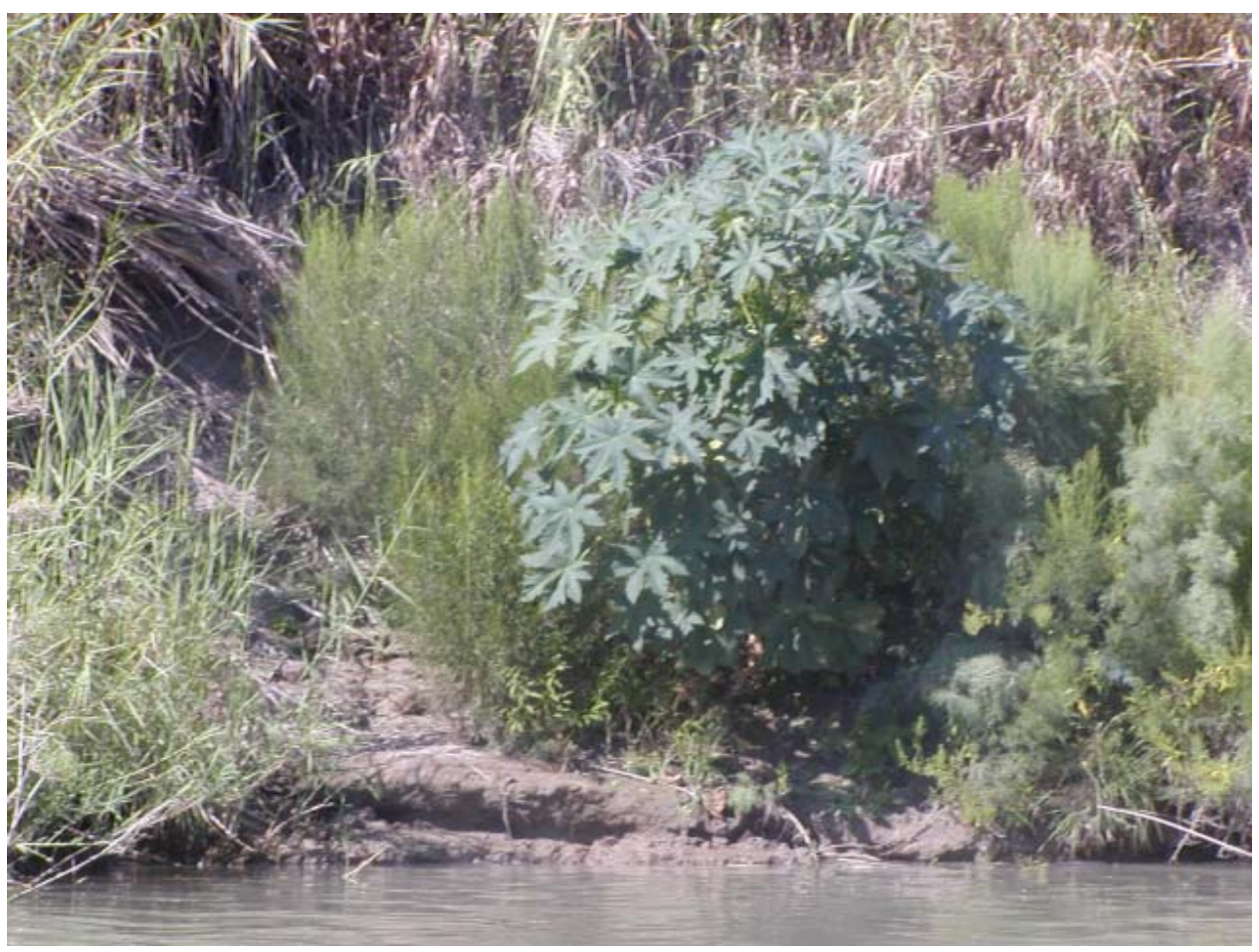

Figure 11. Castorbean invasion along the Rio Grande

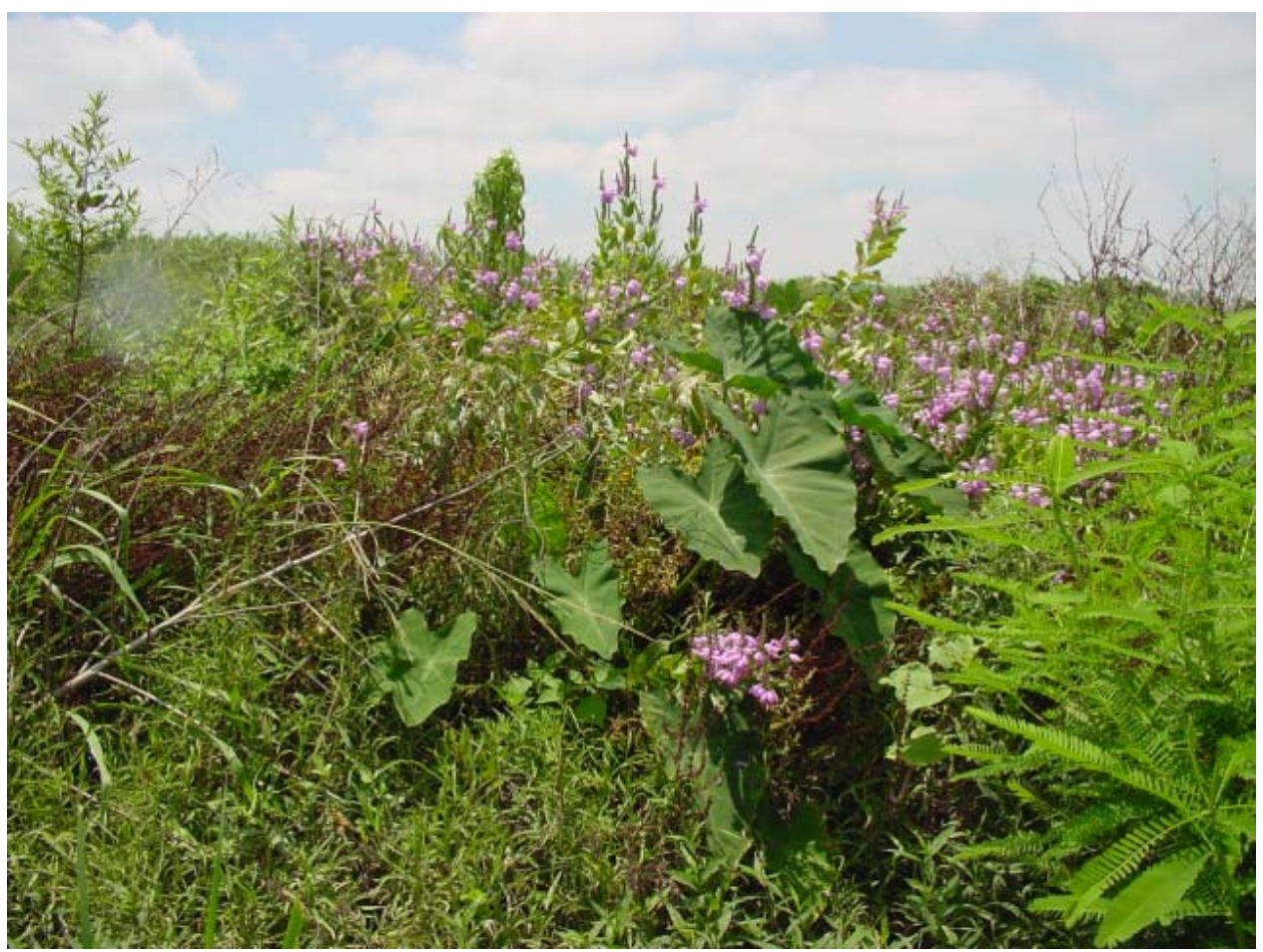

Figure 12. Tentative discovery of Correll's false dragonhead on the Rio Grande 
This area of the river near Del Rio, TX, has the greatest diversity and frequency of native plants for the entire survey area. Diversity of plants decreases farther downstream. Whether this decrease in diversity and frequency is related to habitat, water chemistry, turbidity, competition from weedy, introduced species, or a combination of factors is unclear. Further research is warranted, including implementing more quantitative surveys to determine environmental effects on native plant communities.

Black moss (Lyngbya wollei) was still present and was observed in more areas of the river, although generally as the submersed form. It was not forming the dense, aromatic floating mats observed during the 2003 survey; however, several flood events occurred in 2004, possibly pushing black moss farther down river, or perhaps flushing diluted the nutrient impacts. 


\section{Recommendations}

In agreement with previous reports (Nibling and Grodowitz 2001, Owens et al. 2005), it is important to continue monitoring the river on an annual basis to obtain more accurate and detailed information on the invasive plant problems on the Rio Grande. Boating access is limited, but with the availability of airboats, the help of local agencies (Texas Commission of Environmental Quality, Texas Parks and Wildlife Department, and U.S. Border Patrol) and access to several boat ramps, greater sections of the river can be surveyed.

The 2003 survey report suggested that more quantitative methods should be considered for future monitoring efforts. However, even the use of qualitative surveying methods provides useful information on species presence and the appearance of new, invasive species, such as the discovery of parrotfeather and elephant-ear during the 2003 survey and castorbean in 2004.

According to the Texas Commission on Environmental Quality, water samples are collected from several sections on the Rio Grande and analyzed for nutrient inputs. Data published in 2003 (Texas Clean Rivers Program) indicated that many areas of the river are high in nutrients, especially nitrogen and phosphorus. It is imperative that water chemistry data be accessed or collected to determine nutrient inputs into the river from Mexico and the United States and their relationship to establishment and spread of invasive plant species. It should be noted that many of the large mats of aquatic vegetation in the river are located immediately below outputs from both Mexico and the United States. Management of many of these aquatic plant species in addition to black moss infestations may be related to some extent by reducing nutrient inputs (Figure 13). 


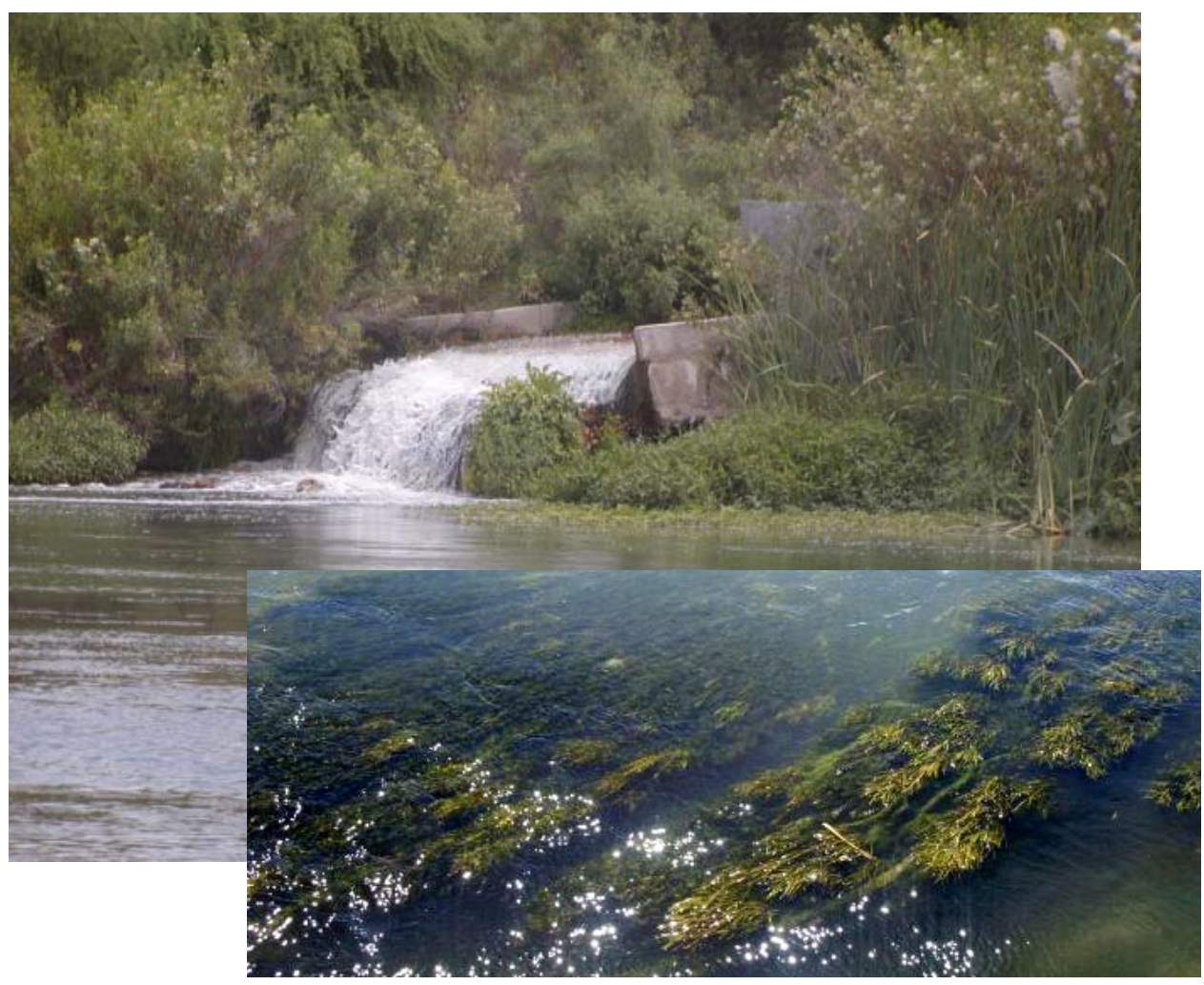

Figure 13. Potential nutrient input from Mexico into the Rio Grande and large intermixed plant bed below outfall 


\section{References}

Chilton, E. W. (2002). "Rio Grande exotic plant status report and action plan," Region M Planning Committee, Aquatic Weed Task Force.

Madsen, J. D., and Owens, C. S. (1998). "Seasonal biomass and carbohydrate allocation in dioecious hydrilla." J. Aquat. Plant Manage. 36, 138-145.

Nibling, F., and Grodowitz, M. J. (2001). "Rio Grande Hydrilla verticillata (L.f.) Royle survey - Summer 2001," Internal Letter Report for the Bureau of Reclamation, Denver, CO.

Owens, C. S., Grodowitz, M. J., and Nibling, F. (2005). "A survey of the invasive aquatic and riparian plants of the lower Rio Grande," ERDC/EL TR-05-6, U.S. Army Engineer Research and Development Center, Vicksburg, MS.

Owens, C. S., Madsen, J. D., Smart, R. M., and Stewart, R. M. (2001). "Dispersal of native and nonnative aquatic plant species in the San Marcos River, Texas.” J. Aquat. Plant Manage. 39, 75-79.

Shearer, J. (2001). "Recovery of endophytic fungi from Myriophyllum spicatum," ERDC TN-APCRP-BC-03, U.S. Army Engineer Research and Development Center, Vicksburg, MS.

Texas Clean Rivers Program. (2003). "Regional assessment of water quality in the Rio Grande Basin," U.S. Section, International Boundary and Water Commission. 


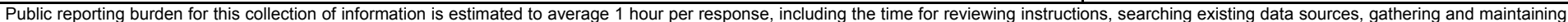

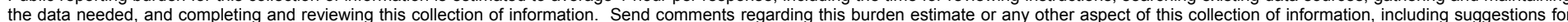

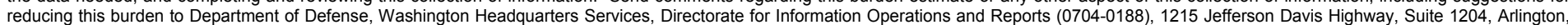

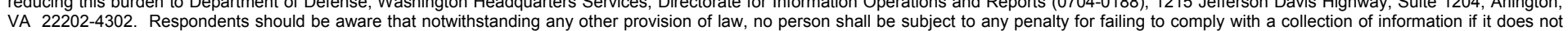
VA 22202-4302. Respondents should be aware that notwithstanding any other provision of law, no person shall be sube
display a currently valid OMB control number. PLEASE DO NOT RETURN YOUR FORM TO THE ABOVE ADDRESS.

\begin{tabular}{l|c}
$\begin{array}{l}\text { 1. REPORT DATE }(D D-M M-Y Y Y Y) \\
\text { September } 2005\end{array}$ & $\begin{array}{c}\text { 2. REPORT TYPE } \\
\text { Final report }\end{array}$ \\
\hline
\end{tabular}

\section{TITLE AND SUBTITLE}

A Survey of the Invasive Aquatic and Riparian Plants of the Lower Rio Grande, 2004

A Survey of the Invasive Aquaic and Riparian Plants of the Lower Rio Grande, 2004

\section{AUTHOR(S)}

Chetta S. Owens, Michael J. Grodowitz, and Fred Nibling

3. DATES COVERED (From - To)

5a. CONTRACT NUMBER

5b. GRANT NUMBER

5c. PROGRAM ELEMENT NUMBER

5d. PROJECT NUMBER

5e. TASK NUMBER

5f. WORK UNIT NUMBER

8. PERFORMING ORGANIZATION REPORT NUMBER

ERDC/EL SR-05-1

Environmental Laboratory, U.S. Army Engineer Research and Development Center, 3909 Halls Ferry Road, Vicksburg, MS 39180-6199
ERDC/EL SR- $05-1$

10. SPONSOR/MONITOR'S ACRONYM(S)
U.S. Army Corps of Engineers

Washington, DC 20314-1000
11. SPONSOR/MONITOR'S REPORT NUMBER(S)

\section{DISTRIBUTION / AVAILABILITY STATEMENT}

Approved for public release; distribution is unlimited.

\section{SUPPLEMENTARY NOTES}

\section{ABSTRACT}

Hydrilla has exhibited extensive range expansion along the Rio Grande since it was first discovered in early 1990 and is now found in areas far removed from the original infestation in Brownsville, TX. Hydrilla, a nonindigenous aquatic plant species, has been implicated in restricted water delivery, inaccurate water accounting, and an overall breakdown of system maintenance. The presence of hydrilla also has had a decided impact on native flora by the formation of extensive monocultures in many areas.

In 2004, surveys were conducted starting below Amistad Reservoir to immediately below Falcon Reservoir to assess the distribution and expansion of hydrilla infestations and document the presence of other invasive aquatic and riparian plant species. A total of seven nonindigenous plant species, hydrilla (Hydrilla verticillata), Eurasian watermilfoil (Myriophyllum spicatum), parrotfeather (M. aquaticum), elephant-ear (Colcasia esculenta), giant cane (Arundo donax), salt cedar (Tamarisk spp.), and castorbean (Ricinus communis) were observed. Hydrilla infestations that were originally discovered during 2003 had increased in size through localized stolon expansion. Also, new hydrilla sites were discovered in 2004, including several directly below Amistad Reservoir. No hydrilla was discovered immediately south of Laredo; however, hydrilla infestations had dramatically increased below Falcon Reservoir. Giant cane continues to spread down river, even displacing well-established common cane (Phragmites australis) below Falcon Reservoir.

(Continued)

\section{SUBJECT TERMS}

Aquatic plant control

Hydrilla

16. SECURITY CLASSIFICATION OF:

\begin{tabular}{|l|l|}
\hline $\begin{array}{l}\text { a. } \text { REPORT } \\
\text { UNCLASSIFIED }\end{array}$ & $\begin{array}{l}\text { b. ABSTRACT } \\
\text { UNCLASSIFIED }\end{array}$ \\
\hline
\end{tabular}

Invasive

Lower Rio Grande

Lower Rio Grande

c. THIS PAGE
UNCLASSIFIED

\begin{tabular}{l|c}
$\begin{array}{l}\text { 17. LIMITATION } \\
\text { OF ABSTRACT }\end{array}$ & $\begin{array}{c}\text { 18. NUMBER } \\
\text { OF PAGES }\end{array}$ \\
& 26 \\
\hline
\end{tabular}

Riparian

19a. NAME OF RESPONSIBLE PERSON

19b. TELEPHONE NUMBER (include area code) 


\section{ABSTRACT (concluded)}

While no new Eurasian watermilfoil sites were discovered in 2004, existing infestations near Del Rio remain stable, extending bank-to-bank and considerable distances down the river. Eurasian watermilfoil fragments, which could lead to the formation of new infestations downstream, were observed in the river. Numerous new sites of parrotfeather, elephant-ear and salt cedar were found during the 2004 survey, and all sites identified in 2003 had increased in localized spread. One endangered wetland plant species, Correll's false dragonhead (Physostegia correllii), was tentatively identified. 